\title{
Reading Public Service Co-Production through the Lenses of Requisite Variety
}

\author{
Maria Vincenza Ciasullo ${ }^{1}$, Rocco Palumbo ${ }^{1} \&$ Orlando Troisi ${ }^{1}$ \\ ${ }^{1}$ Department of Management \& Innovation Systems, University of Salerno, Via Giovanni Paolo II, 132, Fisciano \\ (SA), 84084, Italy
}

Correspondence: Orlando Troisi, University of Salerno, Department of Management \& Innovation Systems, Via Giovanni Paolo II, 132, Fisciano (SA), 84084, Italy. Tel: 089-963-086. E-mail: otroisi@unisa.it

Received: December 22, 2016

Accepted: January 20, 2017

Online Published: January 26, 2017

doi:10.5539/ijbm.v12n2p1

URL: http://dx.doi.org/10.5539/ijbm.v12n2p1

\begin{abstract}
This paper conceives municipalities as Smart Local Service Systems (SLSS), where co-production and variety perform as key resources to merge service quality and sustainability. The attention is focused on local public transport services, where users' involvement in value creation process is considered to be especially relevant. A narrative case study is presented, concerning the mobility service system of the municipality of Bologna (Italy). The research focused on the SMARTIP (Smart Metropolitan Areas Realised Through Innovation \& People) European project, which was aimed at enhancing service quality and sustainability through citizens' empowerment and co-production. Citizens' involvement in co-planning and co-designing local transport services was found to be critical to improve service quality. Citizens' empowerment process allows to establish a co-creating relationship among the different stakeholders who are involved in urban mobility, paving the way for their engagement in devising, implementing and assessing transportation services. Public managers should take into consideration the role of value co-creation to enhance the responsiveness of public sector organizations and to achieve increased smartness. On the one hand, a citizens' empowerment process is required to foster their participation in service co-production; on the other hand, citizens' involvement engenders a virtuous cycle, encouraging the latter in co-producing public services. This paper represents one of the first attempts to examine service co-production in light of the requisite variety perspective. Co-production allows to merge competing purposes by activating the citizens' sleeping assets and by absorbing external variety through the creation of internal variety.
\end{abstract}

Keywords: citizens' empowerment, citizens' engagement, co-creation, co-production, requisite variety

\section{Introduction}

Service co-production is a deep-rooted idea among scholars and practitioners interested in public management (Bovaird, Stoker, Jones, Loeffler, \& Roncancio, 2016). The co-production idea was introduced in late 70s by Ostrom and Ostrom (1977), who pointed out that users' involvement is a distinguishing attribute of public services. Ultimately, co-production assumes that the output of service provision "is always a jointly produced output" (Garn, Flax, Springer, \& Taylor, 1976, pp. 14-15), which is contributed by both regular producers and consumer producers (Parks et al., 1981). Therefore, public service co-production implies a reconceptualization of the relationships between users and providers (Ottmann, Laragy, Allen, \& Feldman, 2011), which relies on value co-creation.

The issues concerning the implementation of public service co-production have been investigated in different fields, including: health care (Palumbo, 2016), social care (Wherton, Procter, Hinder, \& Greenhalgh, 2015), public safety (Alford \& Yates, 2015), and infrastructure-based public services (Wiewiora, Keast, \& Brown, 2016). Scholars have widely emphasised the value added of co-production, discussing its positive effects in terms of: service quality improvement (Radnor Osborne, Kinder, \& Mutton, 2014), increased responsiveness (Marschall, 2004), and service innovation (Alves, 2013). In several cases, the side effects of service co-production have been pointed out. Among others, Fledderus (2015) argued that co-production may hesitate in a process of trust depreciation. Similarly, Williams, Kanga, \& Johnson, (2016) showed that user's involvement paves the way for a process of public value contamination. Last but not least, public service co-production has been argued to increase the degree of uncertainty for public sector organizations (Fledderus, Brandsen, \& 
Honingh, 2015).

It is worth noting that the co-production perspective has been overlooked in the research applied to public transport services, with few - but remarkable - exceptions. Indeed, several studies reveal that users may play a significant role in designing and implementing advanced public transport solutions in periods of financial restrictions (Filippi, Fusco, \& Nanni, 2013). User's involvement has been also found to enhance the travel experience and improve service quality (Nunes, Galvão, \& Cunha, 2014). Besides, service co-production in local public transport services may contribute in the establishment of sustainable community transport system (Fukumoto \& Kato, 2013). Challenging these insights, Echeverri and Skålén (2011) pointed out that enhanced interactions among users and providers may hesitate in value co-destruction when public transport services are concerned. In particular, value co-destruction is argued to be produced by the adoption of conflicting perspectives and diverging aims by the side of both users and providers.

This paper aims to push forward the knowledge in the field of public transport service co-production, conceptualizing it in light of the requisite variety perspective. Rather than paving the way for higher risks of value co-destruction, service co-production is argued to enhance the internal variety of local transport systems, allowing their evolution toward Smart Local Service Systems (SLSS). The following research questions inspired this paper:

R.Q. 1: How service co-production contribute in enriching variety in planning, designing, and delivering public transport services?

R.Q. 2: Are public sector organizations able to autonomously realize the potential of service co-production?

To provide an answer to these research questions, a narrative approach was adopted (Czarniawska, 1997), which was considered consistent with the exploratory purposes of this study (Creswell, 2003). In particular, the experience of the SMARTIP (Smart Metropolitan Areas Realised Through Innovation \& People) European project in the municipality of Bologna was presented in the guise of a descriptive case study.

The manuscript is organized as follows. The second section depicts the theoretical framework, which was used for the purpose of this research. Co-production is assumed to allow public sector organizations to face the growing challenges thrown by external variety by improving internal variety through users' activation and engagement. The third section briefly describes the research strategy and methodology, contextualizing the subject of the case study. The forth section shows the main findings of this research, which are critically discussed in the fifth section of the manuscript. Conclusions summarize the twofold relevance of this paper, which provides scholars with intriguing insights to inspire further developments and points out several practical implications addressed to policy makers and public managers.

\section{Theoretical Framework}

In spite of the need for users' engagement in the process of public value creation (Whitaker, 1980), in late '90s Alford (1998) discussed public service co-production as a road less travelled as compared with the managerialization and marketization of public services. However, in the last decade the increasing fiscal pressures on governments and the growing expectations of the population served contributed in making co-production a common theme in public reforms and policies (Sicilia, Guarini, Sancino, Andreani, \& Ruffini, 2016). In this context, public service co-production is aimed at enhancing the responsiveness and the effectiveness of public sector organizations (Bovaird, Van Ryzin, Loeffler, \& Parrado, 2015). From this point of view, beyond providing services, public sector entities perform as citizens' activators, encouraging them to wake their sleeping assets - that is to say their available resources to participate in the design and delivery of public services - and to use them for the purpose of public value creation (Bovaird et al., 2016).

Different approaches have been suggested to foster user engagement. Among others, Brudney and England (1983) discussed three types of service co-production, which are related to the breadth and depth of users' involvement:

1) Individual co-production (Weaver, 2011), which concerns the one to one relationship between user and provider, who accept to join a co-creating partnership rather than sticking to the traditional relieving approach of public service delivery;

2) Group co-production (Roberts, Greenhill, Talbot, \& Cuzak, 2012), which involves homogeneous groups of users in co-designing and co-delivering public services, in order to enlarge the range of services provided and to improve their responsiveness;

and 3) collective co-production (Ewert \& Evers, 2012), where the population served is encouraged to participate 
in value co-creation, in order to improve the ability of public sector organizations to effectively meet the users' explicit and tacit needs.

Osborne and Strokosch (2013) proposed an alternative taxonomy of co-production approaches, emphasizing the role played by users:

1) Consumer co-production (Gómez \& Jaglin, 2016), which is realized at the operational stage, conceiving co-production as a managerial technique to make the users aware of the special attributes of the service delivery systems;

2) Participative co-production (Tuurnas, 2015), which goes beyond the operational level and concerns simultaneously co-planning, co-design and co-delivery of existing services;

3) Enhanced co-production (Hennala \& Melkas, 2016), which challenges the traditional approaches to public service provision, ascribing to users the role of driver of innovation.

A common trait of these different co-production approaches is that they allow public sector organizations to expand their assets, by activating the sleeping resources of the population served. In other words, it could be argued that service co-production enhances the internal variety of public sector organization, thus improving their ability to meet the growing challenges of the external environment. Sticking to these arguments, a conceptual link between service co-production and requisite variety could be worked out.

The requisite variety construct was formerly developed in the fields of cybernetics and biology to depict fundamental processes of system regulation (Ashby, 1956). In particular, requisite variety concerns the required number of different states that a system should be able to achieve and maintain in order to improve its viability (Ashby, 1958). The adage "variety can destroy variety" (Ashby, 1956, p. 207) represents the underpinning of the law of requisite variety. In other words, to be viable, a system should be endowed with a control mechanism, which allows it to accomplish a number of conditions that is greater than - or, at least, equal to - the number of possible states of the system being controlled (Bartel-Radic \& Lesca, 2011). The more complex and dynamic the system being controlled, the more varied the repertoire of actions allowed by the control mechanism should be to achieve enhanced viability (Ashby \& Goldstein, 2011; Badinelli et al., 2012).

Beer (1979) adapted the law of requisite variety to management, arguing that variety can absorb variety. To be viable, organizations should be able to devise a number of actions which is greater of - at least - equal to the possible states of the external environment (Beer, 1981). Indeed, examining the environmental performance of firms, Lewis and Stewart (2003) claimed that the law of requisite variety should be understood as a fundamental law of organizations. Entities able to increase their internal variety, experience a minimization of costs and risks, collecting sustainable sources of competitive advantages and enhancing their ability to survive their environment (Scala, Purdy, \& Safayeni, 2006).

Scholars have investigated the application of requisite variety to organizations, depicting it as: an essential ingredient of the recipe for increased performance (Morlidge, 2009); a tool to meet market variability (Ojha, White, \& Rogers, 2013); a driver of product innovation (Wiredu, 2007); a managerial approach to diagnose, simulate, and improve business processes (Azadeh, Darivandi, \& Fathi, 2012); a catalyst to organizational learning (Rosendaal, 2009); and a strategic planning instrument (Stephens \& Haslett, 2011). However, the law of requisite variety is still overlooked when examining public sector organizations as well as when discussing public service co-production.

Nevertheless, public service co-production could be conceived as a fundamental process of variety generation (Palumbo, 2016). In fact, citizens' involvement in planning, designing, and delivering public services allow to increase the internal variety of public sector organizations, which could enhance their responsiveness by leveraging on the citizens' assets (Fenwick, 2012). This is true also in the field of local transport services, where all the models of public service co-production suggested by scientific literature could be met. In fact, Nunes et al. (2014) investigated the role of consumer co-production of local public transport services in enhancing the travel experience. Bickerstaff and colleagues (2002) discussed participative co-production in devising local transport policies, exploring citizens' contribution in advancing the responsiveness of local transport systems. Last but not least, a sort of enhanced co-production was analyzed by Truffer (2003), who discussed environmental friendly car sharing services as user-led innovation products.

Drawing on a narrative approach, this study strives for establishing a closer link between public service co-production and requisite variety. The narration concerned a complex co-production experience realized in the municipality of Bologna, which aimed at involving users in a full-fledged co-productive effort to improve the quality and the sustainability of public transport services. 


\section{Methods}

\subsection{Research Design and Methodology}

An exploratory approach was used to meet the exploratory purposes of this paper. A narrative of an experience of transport service co-production is depicted to work out a conceptual link between co-production and requisite variety and to push forward the knowledge in these fields. The narrative is performed in the guise of a descriptive case study (Simons, 2009). This method allowed to deal with the complexity of organizational and social phenomena (Yin, 1999) like local mobility systems, even though it did not allow to arrive at broad generalizations (Yin, 2014). Moreover, the narration paves the way for a thorough examination of people and issues, thus allowing a good grasp of the issue being investigated (Hays, 2004).

Drawing on Yin (2014), this descriptive case study was established on four sequential activities: 1) preparation for data collection, 2) gathering of relevant evidences, 3) analysis of the data collected, and 4) arrangement of the narrative. Sticking to Eisenhardt (1989), different sources of information were accessed. First, a document analysis - including strategic and business plans, policy reports, and information pamphlets - was performed. In light of the findings arising from the document analysis, unstructured interviews were administered to a convenience sample of agents involved in the co-production experience. In sum, 14 interviews were realized, with an average time length for interview of about 90 minutes. All interviews were audio-taped and verbatim transcribed. Lastly, to collect fresh insights, three focus groups involving a convenience sample of citizens who participated in the co-production experience were organized, in order to delve into the following topics: 1) the value added of service co-production; 2) the barriers preventing user engagement; and 3) the way forward to implement co-production in the local transport service system.

The data collected were organized in three electronic worksheets, according to a research protocol, which was agreed by the authors before the data collection process. Each worksheet included the evidence collected through a specific research method, that is to say: document analysis, unstructured interviews, and focus groups. The authors individually examined the data collected, arranging four reports. Then, the research reports were compared, in order to identify inconsistencies and disagreements. All conflicting points were discussed to achieve a common understanding of the investigated topic. When all the inconsistencies were settled, the authors arranged an agreed narration of the co-production experience, which inspired this article.

\subsection{The Subject of the Narration}

Empowering citizens and engaging them in public value creation are the primary purposes of the SMARTIP project. It strives for increasing the citizens' awareness of the role they could play in co-planning, co-designing, and co-delivering innovative public services. Being formerly conceived as a pilot initiative, the SMARTIP project initially involved only three areas: 1) smart engagement; 2) smart environments; 3) smart mobility. Only five cities participated in the launch of this project in 2010, including: 1) Manchester, United Kingdom; 2) Gent, Belgium; 3) Oulu, Finland; 4) Cologne, Germany; and 5) Bologna, Italy. Each pilot unit focused on just one thematic area, with the municipality of Bologna identifying smart mobility as its action field.

The municipality of Bologna is among the most vivid Italian areas in terms of industrial, commercial, and cultural development. External and internal accessibility are two key strengths of Bologna, as reported in its strategic plan (2014). In the last decade the effectiveness of the mobility system of Bologna has been affected by several challenges. Social and economic changes have complicated the local mobility issues of the municipality. In particular, the demographic growth and the movement of families from the city-center to the neighbourhoods, the evolution in the lifestyles of the population, and the increased incoming of tourists, students, and workers from suburban areas have deeply affected the local transport system.

In this context, the municipality of Bologna adhered to the SMARTIP European project, which identified service co-production and value co-creation as crucial tools to enhance the effectiveness of the mobility system of Bologna. The SMARTIP project envisioned the establishment of a networked transport service facility, involving different agents - here included citizens - who share their resources and expertise in order to deal with current mobility issues properly. The agents actively engaged in the project included: mobility managers of the City of Bologna and the Emilia Romagna Region, public transport operators, research centers, a company specialized in the application of information technology in the field of mobility, and citizens established in the municipality of Bologna. The network of agents was coordinated by two project managers, one from the municipality of Bologna and one from the Emilia Romagna Region. The main objective of the network was to design and implement innovative approaches to deal with the challenges affecting the mobility of the municipality of Bologna. 
Table 1. The agents involved in the SMARTIP project

\begin{tabular}{|c|c|c|c|}
\hline Agents & Resources contributed & Individual aims & Collective aims \\
\hline Citizens & $\begin{array}{l}\text { Consumer information, Social } \\
\text { legitimization, Past experiences }\end{array}$ & Service quality, service responsiveness & $\begin{array}{l}\text { Sustainability, } \\
\text { effectiveness }\end{array}$ \\
\hline $\begin{array}{l}\text { Mobility } \\
\text { managers }\end{array}$ & $\begin{array}{l}\text { Public power, Institutional } \\
\text { legitimization, Knowledge }\end{array}$ & $\begin{array}{l}\text { Citizens' satisfaction, Service } \\
\text { effectiveness and efficiency, Public safety }\end{array}$ & Smart mobility \\
\hline $\begin{array}{l}\text { Public Transport } \\
\text { operators }\end{array}$ & $\begin{array}{l}\text { Mobility services, Provider } \\
\text { information, Past experiences }\end{array}$ & $\begin{array}{l}\text { Service efficiency, Service innovation, } \\
\text { Service profitability }\end{array}$ & $\begin{array}{l}\text { Sustainability, } \\
\text { responsiveness }\end{array}$ \\
\hline IT company & $\begin{array}{l}\text { IT- related skills, Knowledge, } \\
\text { Innovative solutions }\end{array}$ & Income, Knowledge advancement & $\begin{array}{l}\text { Smart mobility, Service } \\
\text { innovation, info- mobility }\end{array}$ \\
\hline Research centers & Knowledge, Innovation potential & Institutional legitimization, Income & $\begin{array}{l}\text { Smart mobility, Knowledge } \\
\text { advancement }\end{array}$ \\
\hline
\end{tabular}

Source: authors' elaboration.

\section{Findings}

\subsection{The SMARTIP Project as a Process of Internal Variety Generation}

The SMARTIP project consisted of 4 phases, which were aimed at encouraging citizens involvement in planning and designing local transport services. These phases were characterized by a growing intensity of participants' involvement.

Table 2. The phases of the SMARTIP project

\begin{tabular}{|c|c|c|c|}
\hline Phase & Citizens involved (No.) & Main activities & Variety creation \\
\hline Identification of needs & $\begin{array}{l}1.400 \text { citizens approached, } 859 \\
\text { citizens participating }\end{array}$ & $\begin{array}{l}\text { Collecting information to inspire } \\
\text { local public mobility service } \\
\text { redesign }\end{array}$ & $\begin{array}{l}\text { Variety production due to the } \\
\text { activation of the citizens' } \\
\text { sleeping assets }\end{array}$ \\
\hline Innovation co-design & $\begin{array}{l}54 \text { citizens conveniently selected } \\
\text { among those who participated in the } \\
\text { first phase }\end{array}$ & $\begin{array}{l}\text { Identification of innovative } \\
\text { solutions to inspire service } \\
\text { redesign in the light of the } \\
\text { citizens' value expectations }\end{array}$ & $\begin{array}{l}\text { Variety moduling } \\
\text { identification of and } \\
\text { solutions to improve } \\
\text { mobility }\end{array}$ \\
\hline $\begin{array}{l}\text { Innovative } \\
\text { testing }\end{array}$ & $\begin{array}{l}129 \text { citizens (including } 79 \text { employees } \\
\text { of the Municipality of Bologna, and } 50 \\
\text { frequent travellers) }\end{array}$ & $\begin{array}{l}\text { Testing of innovative solutions } \\
\text { suggested and developed during } \\
\text { the second phase }\end{array}$ & $\begin{array}{l}\text { Variety skimming, to discard } \\
\text { unfeasible solutions or useless } \\
\text { innovations }\end{array}$ \\
\hline Validation & $\begin{array}{l}250 \text { citizens conveniently selected } \\
\text { among those who participated in the } \\
\text { first phase }\end{array}$ & $\begin{array}{l}\text { Validation and implementation } \\
\text { of innovative solutions } \\
\text { suggested }\end{array}$ & $\begin{array}{l}\text { Self- nourishing variety, by } \\
\text { encouraging citizens to } \\
\text { participate in public value } \\
\text { co-creation }\end{array}$ \\
\hline
\end{tabular}

Source: authors' elaboration.

The first phase of the project involved a process of "identification of needs". It aimed at empowering citizens and encourage them to nourish the internal variety of the local transport system. Drawing on the theoretical framework depicted above, a consumer co-production approach was adopted. A sample of 1.400 citizens was randomly built, including those who lived either in the city center or in the suburbs of Bologna. The citizens were informed through both traditional and digital tools about the opportunity to take part into a broad reorganization process of the local mobility system, which relied on user-centeredness. In particular, the participants were asked to participate in a survey administered through a CATI (Computer-Assisted Telephone Interviewing) method. The survey was intended at identifying the mobility-related needs of the served population, in order to inspire the reorganization of the local transport system.

After the first contact, only 97 out of 1.400 citizens (about 7\% of the sample) accepted to participate in the survey. To encourage the involvement in the project, ten online communities were established as potential mediators between the citizens and the municipality of Bologna. Two of them (Tagbolab \& Hyperbole) dealt 
with general topics, aiming at establishing a stronger relationship between citizens and public sector entities operating in Bologna. Alternatively, the remaining eight on-line communities (Free to move, Along the Way, Bike Pride Bologna, Bologna Pedestrian, Bike in Bologna, The Bicycle Consult, Gomypass, and Open Bike) were interested in specific topics related to mobility.

By virtue of the mediating role fulfilled by these communities, the participation rate of the citizens invited to the first phase of the project substantially raised. About $61 \%$ of the sample (859 citizens) accepted to take part in the survey. The on-line communities performed as a sort of citizens' enablers, enhancing their awareness of their co-producing potential and encouraging their involvement in identifying the served population's transport-related needs.

The results of the survey revealed that a large part of the respondents were not satisfied with the ability of the municipality of Bologna to provide timely and adequate information on public transport services (74\%). Poor intermodality was identified as a significant weakness affecting the local mobility system (41\%). Timeliness and quality of travel experiences were considered problematic by $56 \%$ of respondents. About half of the respondents (49\%) complained the poor availability of cycling lanes. Last but not least, the lack of easy-to-access sources of information about mobility were claimed to negatively affect local mobility by most of the respondents (85\%). Web based information tools and social networks were identified as the preferred tools (64\%) to search for information about mobility-related issues.

The information collected during the first step inspired the second phase of the project, which was aimed at "innovation co-design". In this case, a participative co-production approach was used. 54 people-who were conveniently selected among those who participated in the first stage - were involved to represent the different categories of local mobility services for users. To enhance the citizens' innovation potential and minimize the risks of value co-destruction, several catalysts were introduced in this phase, including two specialized research centers in the area of info-mobility and a company specialized in the application of information technology to local mobility systems. On the one hand, these catalysts were called to foster the innovation process by igniting the debate between those who participated in the co-design phase; on the other hand, they performed as moderators of variety generation, by synthesizing citizens' ideas in shared and feasible solutions.

Three tools were used to stimulate the internal variety generation: 1) workshops, aimed at informing the participants about the purposes of the project and raising their awareness; 2) focus groups, intended at developing conceptual ideas to redesign the local mobility system; 3) living labs, meant at translating the conceptual ideas agreed in the previous steps in operative solutions. The second phase of the project paved the way for two main outputs. The participants agreed on a user-centered redesign of the local mobility system, in a perspective of enhanced effectiveness and sustainability, as depicted in the current municipal strategic plan (2014). Moreover, a web-based platform (I Move Smart) was co-designed by citizens and providers, in order to establish a trusted relationship and carry on the co-production efforts.

An enhanced co-production approach inspired the third phase of the SMARTIP project, which involved the "innovative solutions testing". Citizens were encouraged to perform as the main drivers of the transformational innovations. For this purpose, the web-based platform was tested by 8 specialists of the research centers, 4 experts of the IT company, 79 employees of the Municipality of Bologna, and 50 frequent travellers. After three weeks of beta testing, several updates were suggested by frequent travellers to improve the functioning of the platform. These updates concerned the reliability of information about public transport routes, the clarity of public transport timetables, the correct mapping of bike lines, and the availability of timely traffic information.

At the beginning of the "validation" phase, the access to "I Move Smart" was allowed to a convenience sample of 250 citizens, including different categories of users, such as frequent public travellers, bikers, drivers, and observers (umarells). After four weeks, the web-based platform was released with an open-access interface, paving the way for a broad citizens' participation in redesigning the local public transport system. The validation confirmed the reliability on the platform, as well as its effectiveness in collecting meaningful information to improve the functioning of the local mobility system.

Adopting the lenses of requisite variety, the "I Move Smart" platform operated as a sort of variety feeder, allowing citizens to participate in the value co-creation process. In other words, it acted as a springboard to achieve an empowered co-production approach. The citizens' access to the web-based platform gave them the opportunity to perform as full co-producers, who were able to concur without restrictions in planning and designing local transport services. In turn, empowered co-production paved the way for a virtuous cycle of internal variety generation, which enhanced the ability of the local public transport system to meet the growing expectations of the population served. 


\subsection{Engaging Citizens: The Role of Mediators}

As reported above, the SMARTIP project was ultimately aimed at enacting a process of empowered co-production. It strongly relied on citizens' empowerment to realize their involvement in co-planning and co-designing local transport services. However, as pointed out by the mobility manager of the Municipality of Bologna who coordinated the project, “...citizens' engagement turned out to be the most difficult task". This account was echoed by the project co-coordinator, the mobility manager of the Emilia Romagna region, who argued that "...citizens were initially unaware of the purposes of SMARTIP and, consequently, were not willing to take part in the value co-creation process".

The citizens' unwillingness to participate in the co-design of innovative mobility services emerged from the low participation rate observed during the first phase, where only $7 \%$ of the citizens approached accepted to join the project. As pointed out by one of the citizens who took part in all the phases of the project, "... at the beginning (...) we were worried that this initiative was aimed (...) at building consensus, rather than at improving local mobility". In a similar way, another citizen argued that "...it is unlikely that the municipality (...) asks you to have a role in redesigning public services (...) I did not expect to be really engaged in this initiative". In other words, citizens were not confident of their eventual contribution in the process and, as stated by a participant involved in the first step of the project "...I initially rejected to participate (...) because I was worried of wasting my time".

To deal with this issue, ten on-line communities were engaged. They were able to establish a more direct and stronger link with the population approached. As suggested by a member of Hyperbole, “...we performed as spanners (...) as links between municipality and citizens (...) we encouraged citizens to participate in SMARTIP”. Due to the mediating role performed by on-line communities, the citizens' awareness of the purposes and relevance of the project raised, paving the way for a greater commitment to the initiative. The rapid increase in the participation rate after the involvement of the on-line communities was in line with these considerations. In addition, online communities performed as "...trust builders among the citizens", as claimed by a member of Tagbolab.

It is worth noting that different categories of mediators participated in the development phases of SMARTIP, including co-design, testing, and validation of innovative solutions. In these circumstances, mediators performed a quite different role as compared with the previous step. To assist the citizens in devising and developing innovative ideas, three catalysts joined the co-design process, including two research centers and an IT company specialized in the field of mobility. These mediating agents fulfilled two related tasks: on the one hand, they performed as internal variety feeder, catalysing the citizens' innovation potential; on the other hand, they strove for curbing internal variety, in order to match it with external variety and avoid value co-destruction.

As revealed by an IT specialist, “...our role was to incite (...) new ideas to redesign the mobility system (...); moreover, we skimmed the solutions which could not be realized in current circumstances". Similarly, a member of the research team declared that "... we meet greater difficulties in skimming citizens' proposal, rather than in promoting them". In other words, mediators operated as buffers between co-producers and external environment, in order to control the process of variety generation for the sake of efficiency. Echoing these considerations, a citizen argued that "...during the living labs $(\ldots)$ we were struck by the huge number of ideas we suggested". Mediators were crucial in "....synthesizing different ideas in homogeneous solutions and removing impracticable ones". That is to say, mediators amplified the citizens' innovation potential of and enhanced the value co-creation process (Ciasullo et al., 2016).

\subsection{Matching Internal and External Variety}

The three focus groups allowed shedding the light on the value added of service co-production as well as on the barriers preventing citizens' involvement. During the first focus group, several common themes emerged. The participants agreed that citizens' involvement paved the way for ".... a greater awareness of the issues related to mobility". In turn, citizens' awareness enhanced their “...willingness to perform as active agents in the local mobility system". Co-production itself was understood as a "...feasible way to enhance the quality and the responsiveness of local transport services", without affecting the financial sustainability of the municipality. Indeed, the activation of citizens' sleeping resources was pretended to balance the shortage of public resources. Citizens' involvement was also expected to allow the collection of timely and relevant information on the served population's value expectations, thus contributing in the enhancement of the overall effectiveness of the local mobility system.

Challenging these considerations, the second focus group pointed out that several barriers affected the process of service co-production enacted by SMARTIP. "...The lack of trust by the side of citizens" and "...the poor ability 
of the Municipality of Bologna to encourage citizens involvement" were recognized as the main issues preventing service co-production. Actually, when the initiative was launched, “...the lack of clarity of the project purposes" and "...the poor ability of the Municipality to get in touch with the citizens" negatively influenced citizens' engagement. The establishment of mediating agents allowed to overcome the barriers to service co-production. On the one hand, they guaranteed a more direct relationship among citizens and providers; on the other hand, they performed as catalysts and facilitators of co-productive efforts.

The crucial role of mediators was confirmed during the third focus group, which discussed the way forward to achieve enhanced co-production in the local transport system. The citizens recognized the importance of on-line communities in building trust and awareness among participants. "...Even though they are not public organizations (...) the on-line communities are effective in establishing a bridge between citizens and public entities". From this point of view, it is not surprising that the citizens were "...unwilling to take part in the project" as long as they were "....approached by on-line communities". At the same time, the coordinators of the SMARTIP project pointed out that the research centers and the IT company acted as "...feeders and moderators of innovative ideas". From the point of view of requisite variety, they filtered the growing internal variety generated by the process of citizens' involvement and strived for matching it with external variety.

\section{Discussion}

The SMARTIP project revealed an attempt to merge the different approaches to public service co-production suggested by the scientific literature (Brudney \& England, 1983; Osborne \& Strokosch, 2013). In fact, both consumer co-production, participative co-production, and enhanced co-production were exploited to achieve citizens' involvement and to encourage their active participation in public value co-creation. As well, both collective, group, and individual co-production were realized, in order to fully involve the citizens in redesigning the local mobility system. From this point of view, it could be maintained that the SMARTIP project built a smart local service system, which relied on citizens' empowerment and requisite variety to increase the effectiveness and responsiveness of local transport services.

What is even more interesting is that the different approaches to service co-production were not independently implemented. Rather, they were mixed in 'a unanimous effort aimed at citizens' empowerment, which - as suggested in Figure 1 - could be defined "empowered co-production". Consumer and collective co-production, which characterized the first phase of the project, were intended at raising the citizens' awareness of their role in co-planning and co-designing local public transport services. Citizens participated in the process of public value creation by providing information and - consequently - by nourishing the internal variety of the local public transport system indirectly. In the second and third stages, group and participative co-production were mixed, in order to fully realize the citizens' innovation potential. In this case, internal variety was moulded in practicable solutions, which were gradually refined to improve the functioning of the local public transport system. In the fourth and concluding phase, co-production turned to the individual level and was aimed at enhancing the individual contribution in the creation of public value. Citizens were empowered and they contributed in making the local public transport system able to anticipate external variety by enriching its internal variety. Ultimately, co-production allowed to wake the sleeping assets of citizens and to enact them for the purpose of public value creation (Pestoff, 2012).

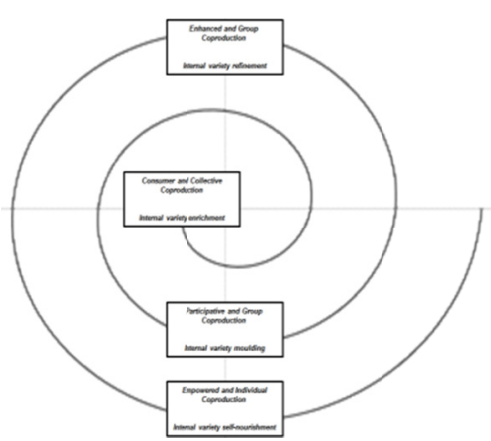

Figure 1. The co-production spiral

The synthesis of the different co-production approaches paved the way for an empowered co-production. Citizens are conceived as co-creating partners of public sector organizations (Gebauer, Johnson, \& Enquist, 
2010). Adopting the lenses of requisite variety, empowered co-production activates a virtuous cycle of self-nourished internal variety (Palumbo, 2015). Citizens actively take part in any phase of the process of value creation, including public service planning, design, and delivery. Obviously, their empowerment improves the ability of public sector organizations to absorb external variety, thus increasing the responsiveness and the quality of public services (Voorberg, Bekkers, \& Tummers, 2015).

Drawing on these considerations, the following answer to R.Q. 1 could be provided. Rather than directly contributing to public value creation, public service co-production enhances the internal variety of public sector organizations: by leveraging on the citizens' sleeping assets, it allows public sector organizations to improve their ability to anticipate the challenges of their competitive environment and to absorb external variety. However, to fully realize the co-production potential, different approaches to citizens' involvement should be simultaneously implemented. In this way, it is possible to raise citizens' awareness and encourage their commitment in public value creation.

The research findings pointed out that citizens were initially unwilling to perform as co-creating partners of public sector organizations. In line with what has been discussed in other studies (Fledderus, Brandsen, \& Honingh, 2015), lack of trust and unawareness explained their low involvement during the initial phases of the SMARTIP process. On-line communities acted as crucial citizens' enablers, encouraging their participation in the redesign of the local public transport system. In other words, on-line communities established a bridge among public sector organizations and citizens, thus removing the barriers raised by the lack of trust and poor awareness. These results echoed what has been found in previous research (Sicilia et al., 2016; Gastil \& Levine, 2005), which emphasizes the role of mediators in promoting citizens involvement. The trust built by on-line communities allowed to establish a strong commitment to the co-production initiative, removing the barriers produced by short-term personal interest of individual co-producers.

Workshops, focus groups and living labs were jointly used to enhance citizens' involvement. In particular, workshops allowed establishing a common thinking among the agents involved in the project, improving their commitment to the project. Focus groups were aimed at co-creating internal variety, encouraging citizens to nourish the redesign of the local public transport system through their sleeping resources. Lastly, living labs moulded the internal variety produced by citizens in practicable innovative solutions. Catalysts enhanced the citizens' innovation potential, skimming unfeasible ideas and establishing a match between internal and external variety.

Hence, the following answer to R.Q. 2 could be provided: mediating agents play a critical role in encouraging citizens' involvement. On the one hand, they allow to establish a trusted relationship among public sector organizations and citizens; on the other hand, they operate as catalysts realize the innovation potential of citizens and enhance their ability to nourish the internal variety of public sector organizations. Different tools can be used for this purpose. Among others, workshops are key to increase the awareness and the self-efficacy of citizens, focus groups are crucial to activate the citizens' sleeping resources and to generate internal variety, and living labs translate internal variety in viable interventions to improve the effectiveness and the responsiveness of local public transport services.

The findings of this manuscript should be read in light of its limitations. The qualitative nature of this study did not allow to generalize its results. Moreover, the focus on a single case produced a subjective bias in the interpretation of the findings, even though it did not affect their relevance. Lastly, the results of the research were affected by the narrative approach adopted, which was not sufficient to build and test grounded theory. Nonetheless, this method was effective in providing an introductory and thick description of the reality being analysed and in paving the way for interesting conceptual and empirical insights.

\section{Conclusions}

The relevance of this paper is twofold. In the first place, it contributes in advancing the scientific knowledge in the field of public service co-production, interpreting it in light of the requisite variety perspective. Co-production is aimed at activating the citizens' sleeping assets, with the eventual purpose of enhancing the internal variety and the responsiveness of public sector organizations. From this point of view, public service co-production is assumed to produce both direct and indirect positive effects: on the one hand, it allows a redesign of public services, which is inspired to the real served population's needs; on the other hand, it activates a virtuous process of self-nourishing internal variety, which is crucial to improve the ability of public sector entities in meeting the growing expectations of the population served.

Even though co-production turns out accessible road to revisit public management, several barriers still prevent its implementation in the public service system. The findings of this paper suggested that the lack of trust by the 
side of citizens and the poor ability of public sector organizations to raise the citizens' awareness of their role in co-creating public value perform as the main barriers to citizen's involvement. Mediating agents are key to encourage citizens' engagement in public service co-production and to overcome the barriers to the establishment of a co-creating partnership among users and providers. From this point of view, public manager should acknowledge and support the role played by mediating agents in realizing the full potential of public service co-production.

This paper encourages further research to push forward the knowledge in the field of public service co-production. Scholars should pay greater attention to the implications of citizens' involvement in terms of internal variety generation, as well as to the ability of public sector organizations to manage public service co-production in order to match internal and external variety. Moreover, the role of mediating agents in establishing a trusted and reliable relationship between public sector organizations should be duly investigated. Last but not least, the role of citizens' involvement in building internal variety and the ability of public sector organizations to synthesize such a variety in order to avoid value co-destruction deserve strong attention, paving the way for a better understanding of the requisites to public value co-creation.

\section{References}

Alford, J. (1998). A public management road less travelled: Clients as co-producers of Public Services. $\begin{array}{lllll}\text { Australian Journal of Public } & \text { Administration, } & \text { 57(4), } & \text { 128-137. }\end{array}$ http://dx.doi.org/10.1111/j.1467-8500.1998.tb01568.x

Alford, J., \& Yates, S. (2015). Co-production of Public Services in Australia: the roles of government organisations and co-producers, Australian Journal of Public Administration, 75(2), 159-175. http://dx.doi.org/10.1111/1467-8500.12157

Alves, H. (2013). Co-creation and innovation in public services, The Service Industries Journal, 33(7-8), 671-682. http://dx.doi.org/10.1080/02642069.2013.740468

Ashby, W. R. (1956). An introduction to cybernetics. London: Chapman \& Hall.

Ashby, W. R. (1958). Requisite variety and itsimplications for the control of complex systems. Cybernetica, 1(2), 83-99. http://dx.doi.org/10.1007/978-1-4899-0718-9_28

Ashby, W.R., \& Goldstein, J. (2011). Requisite variety and the difference that makes a difference: An introduction to W. Ross Ashby's "variety, constraint and law of requisite variety". E:CO, 13(1-2), 190-207.

Azadeh, A., Darivandi, K., \& Fathi, E. (2012). Diagnosing, simulating and improving business process using cybernetic laws and the viable system model: The case of a purchasing process. Systems research and behavioral science, 29(1), 66-86. http://dx.doi.org/10.1002/sres.1102

Badinelli, R., Barile, S., Ng, I., Polese, F., Saviano, M., \& Di Nauta, P. (2012). Viable service systems and decision making in service management. Journal of Service Management, 23(4), 498-526. http://dx.doi.org/10.1108/09564231211260396

Bartel-Radic, A., \& Lesca, N. (2011). Do intercultural teams need "requisite variety" to be effective, International Management, 15(3), 89-104. http://dx.doi.org/10.7202/1005435ar

Beer, A. S. (1979). The Heart of Enterprise. New York (NY): John Wiley.

Beer, A. S. (1981). Brain of the Firm. New York (NY): John Wiley.

Bickerstaff, K., Tolley, R., \& Walker, G. (2002). Transport planning and participation: The rhetoric and realities of public involvement. Journal of Transport Geography, 10(1), 61-73. http://dx.doi.org/10.1016/S0966-6923(01)00027-8

Bovaird, T., Stoker, G., Jones, T., Loeffler, E., \& Roncancio, M. P. (2016). Activating collective co-production of public services: Influencing citizens to participate in complex governance mechanisms in the UK. $\begin{array}{lllll}\text { International Review of Administrative } & \text { Sciences, } & 82(1), & \text { 47-68. }\end{array}$ http://dx.doi.org/10.1177/0020852314566009

Bovaird, T., Van Ryzin, G. G., Loeffler, E., \& Parrado, S. (2015). Activating citizens to participate in collective co-production of Public Services. Journal of Social Policy, 44(1), 1-23. https://doi.org/10.1017/S0047279414000567

Brudney, J. L., \& England, R. E. (1983). Toward a definition of the coproduction concept. Public Administration Review, 43(1), 59-65. https://doi.org/10.2307/975300 
Ciasullo, M. V., Polese, F., Troisi, O., \& Carrubbo, L. (2016). How Service Innovation Contributes to Co-Create Value in Service Networks. In T. Borangiu, M. Dragoicea, \& H. Nóvoa (Eds.), Exploring Services Science, (pp. 170-183). Springer International Publishing. http://link.springer.com/book/10.1007\%2F978-3-319-32689-4

Creswell, J. W. (2003). Research design. Qualitative, quantitative, and mixed methods approaches. Thousand Oaks (CA): Sage Publications.

Czarniawska, B. (1997). A narrative approach to organization studies. Thousand Oaks (CA): Sage Publications.

Echeverri, P., \& Skålén, P. (2011). Co-creation and co-destruction: A practice-theory based study of interactive value formation. Marketing Theory, 11(3), 351-373. https://doi.org/10.1177/1470593111408181

Eisenhardt, K. M. (1989). Building theories from case study research. Academy of Management Review, 14(4), 532-550. https://doi.org/10.5465/AMR.1989.4308385.

Ewert, B., \& Evers, A. (2012). Co-production. Contested meanings and challenges for user organization. In V. Pestoff, T. Brandsen, \& B. Verschuere (Eds.), New Public Governance, the Third Sector, and Co-Production (pp. 61-78). Abingdon, Oxon: Routledge.

Fenwick, T. (2012). Co-production in professional practice: A sociomaterial analysis. Professions and professionalism, 2(2), 1-16. http://dx.doi.org/10.7577/pp.v2i1.323

Filippi, F., Fusco, G., \& Nanni, U. (2013). User empowerment and advanced public transport solutions. Procedia - Social and Behavioral Sciences, 87(1), 3-17. https://doi.org/10.1016/j.sbspro.2013.10.590

Fledderus, J. (2015). Building trust through public service co-production. International Journal of Public Sector Management, 28(7), 550-565. http://dx.doi.org/10.1108/JJPSM-06-2015-0118

Fledderus, J., Brandsen, T., \& Honingh, M. E. (2015). User co-production of public service delivery: An uncertainty approach. Public Policy and Administration, 30(2), 145-164. http://dx.doi.org/10.1177/0952076715572362

Fukumoto, M., \& Kato, H. (2013). An empirical study on sustainable formation of local public transport systems by participation of community members. Paper presented at the 13th World Conference on Transport Research, Rio de Janeiro, Brasil. Paper retrieved from http://www.wctrs-society.com/wp/wp-content/uploads/abstracts/rio/selected/1945.pdf

Garn, H. A., Flax, M. J., Springer, M., \& Taylor, J. B. (1976). Models for indicator development: A framework for policy analysis. Washington, D.C.: The Urban Institute.

Gastil, J., \& Levine, P. (2005). The deliberative democracy handbook: Strategies for effective civic engagement in the 21st Century. San Francisco (CA): Jossey-Bass.

Gebauer, H., Johnson, M., \& Enquist, B. (2010). Value co-creation as a determinant of success in public transport services: A study of the Swiss Federal Railway operator (SBB). Managing Service Quality: An International Journal, 20(6), 511-530. http://dx.doi.org/10.1108/09604521011092866

Gómez, C. D., \& Jaglin, S. (2016). When urban modernisation entails service delivery co-production: A glance from Medellin. Urban Research \& Practice. http://dx.doi.org/10.1080/17535069.2016.1156734

Hays, P. A. (2004). Case study research. In K. B. DeMarrais, \& S. D. Lapan (Eds.), Foundations for research: methods of inquiry in education and the social sciences (pp. 217-234). Mahwah (NJ): Lawrence Erlbaum Associates.

Hennala, L., \& Melkas, H. (2016). Understanding users' collective voice in public service innovation. Knowledge and Process Management, 23(1), 62-72. http://dx.doi.org/10.1002/kpm.1498

Lewis, G. J., \& Stewart, N. (2003). The measurement of environmental performance: An application of Ashby's law. Systems Research and Behavioral Science, 20(1), 31-52. http://dx.doi.org/10.1002/sres.524

Marschall, M. J. (2004). Citizen participation and the neighborhood context: A new look at the coproduction of local public goods. Political Research Quarterly, 57(2), 231-244. http://dx.doi.org/10.2307/3219867

Morlidge, S. P. (2009). Money, time and variety engineering: The application of cybernetics to the diagnosis and design of financial performance management systems. Systemic Practice and Action Research, 22(4), 235-247. http://dx.doi.org/10.1007/s11213-009-9124-1

Municipality of Bologna. (2014). Strategic Metropolitan Plan, Bologna: Chialab. 
Nunes, A. A., Galvão, T., \& Cunha, J. F. (2014). Urban public transport service co-creation: Leveraging passenger's knowledge to enhance travel experience. Procedia - Social and Behavioral Sciences, 111(1), 577-585. http://dx.doi.org/10.1016/j.sbspro.2014.01.091

Ojha, D., White, R. E., \& Rogers, P. P. (2013). Managing demand variability using requisite variety for improved workflow and operational. International Journal of Production Research, 51(10), 2915-2934. http://dx.doi.org/10.1080/00207543.2012.748230

Osborne, S.P., \& Strokosch, K. (2013). It takes two to tango? Understanding the co-production of Public Services by integrating the Services Management and Public Administration Perspectives. British Journal of Management, 24(S1), 31-47. http://dx.doi.org/10.1111/1467-8551.12010

Ostrom, V., \& Ostrom, E. (1977). Public goods and public choices. In E. Savas (Ed.), Alternatives for delivering public services. Toward improved performance (pp. 7-49). Boulder, CO: Westview.

Ottmann, G., Laragy, C., Allen, J., \& Feldman, P. (2011). Coproduction in practice: Participatory action research to develop a model of community aged care. Systemic Practice and Action Research, 24(5), 413-427. http://dx.doi.org/10.1007/s11213-011-9192-x

Palumbo, R. (2015). Requisite variety in action: The "Giffoni experience" case study. Paper presented at the $15^{\text {th }}$ EURAM Annual Conference, Varsaw. Abstract retrieved from http://2015.euramfullpaper.org/program/search.asp?qs=UNIVERSITY\%20OF\%20SALERNO

Palumbo, R. (2016). Contextualizing co-production of health care: A systematic literature review. International Journal of Public Sector Management, 29(1), 72-90. http://dx.doi.org/10.1108/IJPSM-07-2015-0125.

Parks, R. B., Baker, P. C., Kiser, L., Oakerson, R., Ostrom, E., Ostrom, Percy, S. L., Vandivort, M. B., Whitaker, G. P., \& Wilson, R. (1981). Consumers as coproducers of Public Services: Some economic and institutional $\begin{array}{llll}\text { considerations. } & \text { Policy } & \text { Studies } & \text { Journal, }\end{array}$ http://dx.doi.org/10.1111/j.1541-0072.1981.tb01208.x

Pestoff, V. (2012). Co-production and Third Sector Social Services in Europe. Some Crucial Conceptual Issues. In V. Pestoff, T. Brandsen, \& B. Verschuere (Eds.), New Public Governance, the Third Sector, and Co-Production (pp. 13-34). Abingdon, Oxon: Routledge.

Radnor, Z., Osborne, S. P., Kinder, T., \& Mutton, J. (2014). Operationalizing co-production in public services delivery: The contribution of service blueprinting. Public Management Review, 16(3), 402-423. http://dx.doi.org/10.1080/14719037.2013.848923

Roberts, A., Greenhill, B., Talbot, A., \& Cuzak, M. (2012). "Standing up for my human rights": A group's journey beyond consultation towards co-production. British Journal of Learning Disabilities, 40(3), 292-301. http://dx.doi.org/10.1111/j.1468-3156.2011.00711.x

Rosendaal, B. W. (2009). Sharing knowledge, being different and working as a team. Knowledge Management Research and Practice, 7(1), 4-14. http://dx.doi.org/10.1057/kmrp.2008.32

Scala, J., Purdy, L., \& Safayeni, F. (2006). Application of cybernetics to manufacturing flexibility: A systems perspective. Journal of Manufacturing Technology Management, 17(1-2), 22-41. http://dx.doi.org/10.1108/17410380610639489

Sicilia, M., Guarini, E., Sancino, A., Andreani, M., \& Ruffini, R. (2016). Public services management and co-production in multi-level governance settings. International Review of Administrative Sciences, 82(1), 8-27. http://doi.org/10.1177/0020852314566008

Simons, H. (2009). Case Study Research in Practice. London: Sage Publishing.

Stephens, J., \& Haslett, T. (2011). A Set of conventions, a model: An application of Stafford Beer's viable systems model to the strategic planning process. Systemic Practice and Action Research, 24(5), 429-452. http://doi.org/10.1007/s11213-011-9194-8

Truffer, B. (2003). User-led innovation processes: The development of professional car sharing by environmentally concerned citizens. Innovation: The European Journal of Social Science Research, 16(2), 139-154. http://dx.doi.org/10.1080/13511610304517

Tuurnas, S. (2015). Learning to co-produce? The perspective of public service professionals. International Journal of Public Sector Management, 28(7), 583-598. http://dx.doi.org/10.1108/IJPSM-04-2015-0073

Voorberg, W. H., Bekkers, V. J., \& Tummers, L. G. (2015). A systematic review of co-creation and co-production: 
Embarking on the social innovation journey. Public Management Review, 17(9), 1333-1357. http://dx.doi.org/10.1080/14719037.2014.930505

Weaver, B. (2011). Co-producing community justice: The transformative potential of personalisation for penal sanctions. British Journal of Social Work, 41(6), 1038-1057. http://dx.doi.org/10.1093/bjsw/bcr011

Wherton, J. S. P., Procter, R., Hinder, S., \& Greenhalgh, T. (2015). Co-production in practice: How people with assisted living needs can help design and evolve technologies and services. Implementation Science, 10(1), 75-84. http://dx.doi.org/10.1186/s13012-015-0271-8

Whitaker, G. P. (1980). Coproduction: Citizen participation in service delivery. Public Administration Review, 40(3), 240-246. http://dx.doi.org/10.2307/975377

Wiewiora, A., Keast, R., \& Brown, K. (2016). Opportunities and challenges in engaging citizens in the co-production of infrastructure-based public services in Australia. Public Management Review, 18(4), 483-507. http://dx.doi.org/10.1080/14719037.2014.999820

Williams, B. N., Kanga, S. C., \& Johnson, J. (2016). Co-contamination as the dark side of co-production: Public value failures in co-production processes. Public Management Review, 18(5), 692-717. http://dx.doi.org/10.1080/14719037.2015.1111660

Wiredu, G. O. (2007). Coordinating global software development activities: Requisite variety in Information systems as a dependent variable. Paper presented at the IFIP $8.2 \& 9.5$ Conference on Virtuality and Virtualization, Portland, OR. Abstract retrieved from: https://ulir.ul.ie/handle/10344/1190

Yin, R. K. (1999). Enhancing the quality of case studies in health services research. Health Services Research, 34(5), 1209-1224.

Yin, R. K. (2014). Case study research: Design and methods. Thousand Oaks, CA: Sage Publishing.

\section{Copyrights}

Copyright for this article is retained by the author(s), with first publication rights granted to the journal.

This is an open-access article distributed under the terms and conditions of the Creative Commons Attribution license (http://creativecommons.org/licenses/by/4.0/). 